\title{
Poverty and Critique in the Modern Working Society
}

\section{Gottfried Schweiger}

Poverty is more than a 'welfare status' among others. In this paper I want to show that poverty is not only a failure of distribution of income but that it is a state of humiliation. In the first section I will examine poverty knowledge, how poverty is conceptualised and what norms are inherent in the measures of the poor. In the second section I will show that poverty is humiliating because it is bound to failure and deficiency. To be poor means to be unable to take care for oneself. In the third and final section I will turn to social critique and its relation to the subjects of poverty. There are good reasons to be sceptical of the poor and their judgements and to seek for objective criteria, but this cannot replace the subject and their experience.

Keywords: Poverty; Social Critique; Humiliation; Work

The ongoing economic crisis has hit the labour markets and led to a significant increase in unemployment, especially in the southern European countries such as Spain, Italy and Greece. While the causes for this downturn are still being debated by social scientists and economists, politicians have started to implement extensive austerity measures, cut spending on social welfare and increase taxes. As a consequence, poverty, in all its different forms, is a rising issue in all modern welfare states. In 2012, the European Union counted around 124 million people who were in danger of being socially excluded, which means that they were at risk of (monetary) poverty, severely materially deprived or living in a household with low work intensity. ${ }^{1}$ This is an increase of nearly ten million people since 2009. In the USA, 46.5 million people or 15 per cent were living in poverty in 2012, up from 37.3 million in 2007 and 31.6 million in $2000 .^{2}$ This is the largest number in the 54 years for which poverty rates have been published. ${ }^{3}$ It seems obvious that these developments are somehow bad. They are bad for the states, the societies and the individuals

\footnotetext{
${ }^{1}$ See the official data from Eurostat: http://ec.europa.eu/eurostat

2 See the official data of the US Bureau of Census: http://www.census.gov/hhes/www/poverty/

${ }^{3}$ Ibid.
} 
that are harmed. It is bad to be unemployed or to be homeless. Maybe some of these things are not only bad but morally wrong. Maybe they are unjust. To reach such a verdict is a complex task and it is not clear what it adds to our knowledge about the crisis, about poverty or about state deficits. Is it unjust to lose one's job because the company is struggling because of a decrease in demand? Is it morally wrong if a state decides to help its financial sector and in the same breath cuts the family allowance? And does it violate any normative principles if the stock markets collapse and take billions with them? Even if it is very unlikely that philosophers will agree on their respective answers, these questions should not be all too easily dismissed. They demand our thorough attention, especially if we want to engage in what could be called a critical inquiry of capitalistic societies. Critical theories-which do not have to be affiliated to Critical Theory-are needed in such times of unrest, crisis and change. They can help us to understand the deeper roots and causes of the social and economic upheavals that leave so many behind, and to develop measures and strategies to overcome them.

Now, in this paper I want to explore poverty in the welfare state and its normative significance. To be more precise, I want to examine the subject of poverty. What do we know if we know that someone is poor? How can this knowledge be used to criticise the social relations that produce such conditions of poverty? What does poverty tell us about the welfare state? What does poverty tell us about capitalism, about the social relations we live in? These questions are familiar to Alice O'Connor's critical examination of poverty knowledge in the USA and its shift away from the social structures that produce poverty to the social reality of the poor. She rightly criticises the fact that poverty research has been reduced to counting the poor instead of asking why there are poor people at all.

Although liberal in origins, poverty knowledge rests on an ethos of political and ideological neutrality that has sustained it through a period of vast political change. Very much for this reason, it can also be distinguished by what it is not: contemporary poverty knowledge does not define itself as an inquiry into the political economy and culture of late twentieth-century capitalism; it is knowledge about the characteristics and behavior and, especially in recent years, about the welfare status of the poor. ${ }^{4}$

I agree that poverty research should be at the forefront of social critique rather than feeding politicians with the knowledge they need to reorganise the welfare state; and I think that scientific knowledge about poverty and about the poor can tell us a lot about today's society and today's capitalism. Poverty is much more than a 'welfare status' among others. I want to show not only that poverty is a failure of distribution of income or commodities but also that it is a state of humiliation. Poverty is to fail to merit being part of society-which tells us a lot about how merit is understood in capitalistic societies. Poverty is the mirror of a capitalistic understanding of meritocracy, which inevitably produces losers and failures.

\footnotetext{
${ }^{4}$ Alice O'Connor, Poverty Knowledge: Social Science, Social Policy, and the Poor in Twentieth-century U.S. History, 1st edn (Princeton, NJ: Princeton University Press, 2001), p. 4.
} 
In the first section I will examine poverty knowledge, how poverty is conceptualised and what norms and limits are inherent in the measures of the poor. To be poor has to do with three dimensions, having, being and doing-not to have something, not to be something and not to be able to do something. It is falling short in comparison with standards that are called 'normal'. In the second section I will show that poverty is much more than a neutral condition; it is humiliating because it is bound to failure and deficiency. The poor are the defective goods produced by the market. They are treated as such by social policy and workfare, which views employability as the main quality of any valuable member of society, and the failure to be successful as an individual fault. In the third and final section I will turn to social critique and its relation to the subjects of poverty. Where do the poor fit in when it comes to criticising poverty or capitalism or injustice? There are good reasons to be sceptical of the poor and their judgements and to seek for objective criteria, but this cannot replace the subject and their experience.

\section{Poverty Knowledge and the Power to Measure}

Poverty research has produced immense knowledge about poverty and the poor. Despite the fact that there is no common understanding of a definition of poverty, many details about living in poverty have been surveyed and the poor have been counted in many different ways. ${ }^{5}$ This is true for all kinds of poverty and for many different geographical, political and social spaces. One main distinction that often also serves as a distinction between poverty in developing countries and poverty in developed and industrialised countries is the one between absolute poverty and relative poverty, between concepts that aim to understand poverty in absolute terms and those which insist that poverty is a relative concept throughout. ${ }^{6}$ On the worldwide scale, absolute concepts are most often used because the aim is to know how many people are 'really' poor. Absolute measures target the basic features of human life. Relative poverty is the poverty we can find in the developed countries like those with a modern welfare state, where almost no one has to die because they are poor, and where the standard of living is high for everyone, even for the poor. So the distinction between relative and absolute poverty can also mark the distinction between being 'really' poor and 'just' poor in this or that context. The relatively poor are relatively rich in comparison to the absolutely poor. Also, the moral status of absolute poverty appears to be clearer and maybe even obvious. It is wrong to be absolutely poor whatever the reasons, but the distinction between absolute and relative poverty faces various critics and difficulties, which may lead to the conviction

\footnotetext{
${ }^{5}$ Paul Spicker, 'Definitions of Poverty: Twelve Clusters of Meaning' in Paul Spicker, Sonia Alvarez Leguizamón and David Gordon (eds) Poverty: an International Glossary, 2nd edn (London: Zed Books, 2007), pp. 229-243.

${ }^{6}$ Caterina Ruggeri Laderchi, Ruhi Saith and Frances Stewart, 'Does It Matter That We Do Not Agree on the Definition of Poverty? A Comparison of Four Approaches' in Mark McGillivray and Matthew Clarke (eds) Understanding Human Well-being, 1st edn (Tokyo: United Nations University Press, 2006), pp. 19-53.
} 
that poverty is both relative and absolute, that relative concepts rest on an absolute core, and that absolute concepts are always relative to certain standards or conditions. This is of importance to understand poverty in general and to understand poverty in the welfare state.

Poverty conceptualised as relative to a given standard of living implicitly claims that, whatever this standard is and however it is set or measured, it can serve as a viable benchmark. Amartya Sen showed in his critique of relative concepts that what poverty defines is that it is somehow bad for the poor, that poverty is not a neutral state of having less than others but a state of not having enough. ${ }^{7}$ Relative measures may use other standards than absolute ones, but they still claim that failing to reach these standards means not having enough: not enough for participation, for feeling an equal member of society or for living a decent life. The famous description of poverty from Peter Townsend makes this clear. Here the 'ordinary living patterns, customs and activities' serve as the normative benchmark. It is morally wrong to fail them.

Individuals, families and groups in the population can be said to be in poverty when they lack the resources to obtain the type of diet, participate in the activities and have the living conditions and amenities which are customary, or are at least widely encouraged or approved, in the societies to which they belong. Their resources are so seriously below those commanded by the average individual or family that they are, in effect, excluded from ordinary living patterns, customs and activities. ${ }^{8}$

Likewise, the critique of absolute concepts, which refer either to a set of basic capabilities or a monetary poverty line, shows that they are relative in themselves. Monetary poverty lines are relative to what one can buy with this money. They are relative to the family situation, whether they can offer support, shelter, food or other goods. Money can be used differently if one is living in a moderate climate or if one needs expensive winter clothes. The same is true for all other goods. Even the most basic of them vary between individuals with different physical conditions and different life plans. Hunger appears to be a clear indicator of poverty, but some religious people undergo hunger because they want to. Are they poor? The answer of the capability approach is to value freedom and to define absolute poverty as the inability to choose. ${ }^{9}$ Yet are people poor who are adrift on the sea without water and food? Or are those people poor who lived a few thousand years ago and died because of a drought with no chance of doing anything about it? It seems odd to call these people poor even if they had no choice. Poverty is called poverty because it could also not be, because it could be different, because someone-whoever that may be-could do something about it. ${ }^{10}$ Poverty,

\footnotetext{
7 Amartya Sen, 'Poor, Relatively Speaking', Oxford Economic Papers 35:2 (1983), pp. 153-169.

8 Peter Townsend, Poverty in the United Kingdom. A Survey of Household Resources and Standards of Living, 1st edn (Berkeley, CA: University of California Press, 1979), p. 31.

9 Ingrid Robeyns, 'The Capability Approach: a Theoretical Survey', Journal of Human Development, 6:1 (March 2005), pp. 93-114; Ingrid Robeyns, 'The Capability Approach in Practice', The Journal of Political Philosophy, 14:3 (2006), pp. 351-376.

10 Elke Mack et al. (eds), Absolute Poverty and Global Justice: Empirical Data, Moral Theories, Initiatives, 1st edn (Farnham: Ashgate, 2009).
} 
even absolute poverty, is relative to what is possible, under the given circumstances, with regard to the technical possibilities.

So I think it is best to conceptualise poverty as relative and absolute and to acknowledge that relative and absolute elements are intertwined. Poverty can vary from society to society, even between different communities, and-in the endbetween different individuals, and every concept and measure sets its normative benchmark. It has to unless it wants to become arbitrary. I think that there are three candidates to be used as the core concept which are not mutually exclusive but rather refer to different dimensions of human life: having, being, doing. Poverty means to not have something, it means to not be something, and it means to not be able to do something. Poverty is characterised negatively. It is not a positive concept, nor is being poor something positive. Almost every poverty concept refers to one or more of these three dimensions. Monetary poverty lines tell us that having less than a certain amount of money means being poor. The Human Development Index tells us that not being able to read and a lack of formal education are strong indicators of being poor. For the European Union, not being included means being poor. Those three not only often relate to each other-which means that, for example, having less can translate into not being able to do something and vice versa-but they are also generalisations that cannot capture the whole picture. Some are included that might not be poor and some are not included that might be poor. Poverty research has to deal with the problem that on the one hand poverty is individual and on the other it needs to be generalised. Poverty research has to balance this dialectic of the concrete and the general. It presents thick descriptions and statistical data. One description reports that there are basically no poor in Europe at all-using the World Bank's poverty line of US\$1.25 a day; in other studies one can find hunger and nutritional poverty in Germany and the USA. ${ }^{11}$

This shows that we have to be critical of poverty knowledge and that it is messy rather than unified. It reflects the multidimensionality of poverty that is stressed so often. It also reflects one problem that comes with poverty, especially in the context of highly developed countries, in the context of the welfare state. While in absolute measures the benchmark of what poor people do not have, what they are not able to do and what they are not is set very low and sometimes only consists of what humans need to exist and survive-shelter, food, water and sanitation-these benchmarks do not work in the welfare state. Nobody would be poor here. Poverty in the welfare state is different to poverty in a refugee camp or in the slums of New Delhi, but it is poverty nonetheless. It also combines absolute and relative elements. It is not only relative.

\footnotetext{
11 Alisha Coleman-Jensen et al., Household Food Security in the United States 2010, Economic Research Reports (Washington, DC: US Departement of Agriculture, September 2011), http://www.census.gov/prod/ 2011pubs/p60-239.pdf; Sabine Pfeiffer, Tobias Ritter and Andreas Hirseland, 'Hunger and Nutritional Poverty in Germany: Quantitative and Qualitative Empirical Insights', Critical Public Health, 21:4 (December 2011), pp. 417-428, doi: 10.1080/09581596.2011.619519; World Bank, World Development Indicators 2011 (Washington, DC: World Bank, April 2011), http://siteresources.worldbank.org/DATASTATISTICS/Resources/wdi_ebook.pdf
} 
One possible measure for defining the poor used in the European Union is material deprivation, or to be precise, in the context of the Europe 2020 agenda, the indicator is severe material deprivation. ${ }^{12}$ This means the inability to afford four out of nine basic activities that are set as normal or standard in the European Union. The list is as follows: people cannot afford to (1) pay their rent or utility bills; (2) keep their home adequately warm; (3) face unexpected expenses; (4) eat meat, fish or a protein equivalent every second day; (5) enjoy a week's holiday away from home once a year; (6) have a car; (7) have a washing machine; (8) have a colour TV; or (9) have a telephone. These basic activities, services and goods are determined through surveying the opinions of experts and the general population. ${ }^{13}$ Only if a great majority of the population thinks that something is normal, in the sense that everybody should be able to have or do it, is it included in this list. The list can vary, as can the definition that deprivation means failing to afford four of these items. Simple material deprivationwhich is in some sense not severe-is defined by the inability to afford three out of those nine items. In Austria there is also the indicator of financial deprivation which is defined by four out of eight, slightly different items. Other countries use or have used similar measures. Whatever the indicator that determines poverty looks like, it refers to a standard of normality, whether this standard consists of seven, eight or nine items.

Therefore, being severely materially deprived, which means being poor, means to fail this standard. To live an abnormal life. Again, choice is crucial. One is materially deprived if, and only if, one has no other choice, if one cannot afford the things on the list even if one wants to. So what is seen as normal here is the standard of living that is reached by the majority. To be poor means to be unable to be part of this majority. The normative benchmark of poverty is to be able to do, have and be what most do, have and are. Then, and only then, is one part of this society. Belonging is the key, and belonging is not to be understood formally. One does not belong to society just because one is a citizen or because one is equal before the law; belonging is translated into having some things, to be able to do some things, and that one is someone: not poor. One is included.

Starting from such a concept, the counting and surveying can begin. People are asked and categorised as: at risk of poverty, materially deprived or unemployed. ${ }^{14} \mathrm{We}$

12 Anthony B. Atkinson and Eric Marlier, 'Living Conditions in Europe and the Europe 2020 Agenda' in Income and Living Conditions in Europe, 1st edn, Eurostat Statistical Books (Luxembourg: Publications Office of the European Union, 2010), pp. 21-35, http://epp.eurostat.ec.europa.eu/portal/page/portal/product_details/ publication?p_product_code=KS-31-10-555; European Commission, The Social Dimension of the Europe 2020 Strategy. A Report of the Social Protection Committee (2011), Social Europe (Luxembourg: Office for Official Publications of the European Communities, 2011), http://ec.europa.eu/social/BlobServlet?docId=6895\&langId=en

13 Anne-Catherine Guio, What Can Be Learned from Deprivation Indicators in Europe, Eurostat Methodologies and Working Papers (Luxembourg: Office for Official Publications of the European Communities, 2009), http://epp.eurostat.ec.europa.eu/cache/ITY_OFFPUB/KS-RA-09-007/EN/KS-RA-09-007-EN.PDF

14 Alessio Fusco, Anne-Catherine Guio and Eric Marlier, 'Characterising the Income Poor and the Materially Deprived in European Countries' in Anthony B. Atkinson and Eric Marlier (eds) Income and Living Conditions in Europe, op. cit., pp. 133-153, http://epp.eurostat.ec.europa.eu/portal/page/portal/product_details/publication? p_product_code=KS-31-10-555; Brian Nolan and Christopher T. Whelan, Poverty and Deprivation in Europe (Oxford: Oxford University Press, 2011). 
know that the unemployed are the most endangered group. We know that migrants are more likely to be affected. We know that young people and children as well as the elderly are more often poor than the middle-aged. We know that disability and chronic illness are often connected with deprivation. In short, we know that certain groups more often fail the standards of normality than others, that they are poor for longer, and that they are more often poor and that they bequest their poverty to their children. ${ }^{15}$ We know this and we know that the rates of material deprivation differ between the member states of the European Union, that the new member states such as Poland, Romania and Bulgaria have deprivation rates two or three times as high as those in Sweden, Germany and the UK. The standard of normality is set for the whole Union and more than 50 per cent of the people in Romania fail this standard. They suffer from severe material deprivation. Yet still Romania is a highly developed country and there is basically no absolute poverty in the sense of the World Bank or the Human Development Index.

It is important to note that this material deprivation indicator is still a relative rather than an absolute measure: it is only by rich country standards that the lack of a colour television or a car or a week's holiday away from home (all counted as deprivations in the EU's indicator) could be regarded as signs of inadequate living standards. This reflects the standing of even the poorest countries in the EU as members of the rich world: Romania and Bulgaria, for example, the two poorest EU states, rank among the top third of nations in the world on the UNDP's Human Development Index and the World Bank classifies them as 'upper middle income' countries. ${ }^{16}$

The poor of Europe are the middle class of the world. They are just not able to be normal, or behave and act normally, in the sense of their peers. Whatever details poverty research produces about the poor, what we learn about the causes, consequences and the effects of poverty, about the lives and the hardships of the poor, behind all this lie various concepts of normality, the normal life of the others as the benchmark.

\section{The Market and Humiliation}

Poverty means not to have and not to be able to do things that are classified as normal. The standards are relative but they are nonetheless 'hard' and they are not subjective. For most people, including the poor, it is no exit strategy to pretend that these standards do not apply or to deny their relevance. They might not be set in stone but they are strong in social relations and in people's minds. I have pointed out that, whatever we know about poverty and about the living conditions of the poor

\footnotetext{
15 Greg Duncan and Jeanne Brooks-Gunn (eds), Consequences of Growing up Poor (New York: Russell Sage Foundation, 1997); Stephen P. Jenkins and Thomas Siedler, The Intergenerational Transmission of Poverty in Industrialized Countries, 1st edn, CPRC Working Paper 75 (Manchester: Chronic Poverty Research Centre, 2007), http://cprc.abrc.co.uk/pdfs/75Jenkins_\%28Siedler\%29.pdf

${ }^{16}$ Tony Fahey, Poverty and the Two Concepts of Relative Deprivation, 14, Working Paper Series (Dublin: UCD School of Applied Science, July 2010), www.ucd.ie/t4cms/wp15\%20fahey.pdf
} 


\section{G. Schweiger}

and however they are counted, one main assumption is that being poor is bad, that it is wrong and that it not only could be different but that it should be different, that there should be no poor, or at least there should be far fewer, and that everyone should have the ability and opportunity to be normal and have a certain standard of living. Is it simply the normativity of the majority that poverty research reproduces? I think that poverty knowledge can tell us more. In reference to normality or to other often used measures such as being at risk of poverty, defined by an income of less than 60 per cent of the median income, the modern society not only reproduces itself and sets itself as the standard, but it delivers a judgement, a judgement different from the one that is also often bound to the term 'poverty', the judgement that poverty is bad and wrong.

Poverty as a thick concept - that contains descriptive and normative elements-can be loaded with many different assumptions, and the moral sentiment that we should be sorry for the poor is just one possible example of it. An often unexpressed judgement is that poverty is not only a hardship, that it is not only not good to be poor but that it is also a failure. Poverty is humiliating. It is humiliating because being poor means failing to achieve not only the standards set in different items or poverty lines, but what modern societies value the most: personal freedom and responsibility. Being poor means being unable to take care of oneself. One is free but cannot use this freedom properly and translate it into a normal standard of living. Peter Schaber has explicated this from a different point of view. He claims that the inability to look after oneself, and being dependent on others, is what makes poverty morally wrong.

Poverty, I have argued, does not violate the dignity of human beings because poor people lack vitally important goods. Neither does it violate dignity because poor people, due to poverty, are unable to realise their rights. Poverty violates human dignity, because, and insofar as, poor people are dependent on others in a specific way. It violates dignity when it is responsible for the fact that a person's survival and her way of survival are placed at the mercy of others. Individuals who have to live in poverty are not able to stand up to others when it comes to securing their own survival. ${ }^{17}$

I support this conclusion-from a different point of view-and I think that it is rooted in how societies look and how personal responsibility and freedom are understood. It is bound to the market and to market success. The most important market in modern societies is without any doubt the labour market. It is the universal integration machine. If one is not part of it, one needs a lot of other assets to compensate. However, the non-working millionaires, the lucky lottery winners and the trust babies are a small minority, as are the happy dropouts. The female role of motherhood and housewife might be an acceptable non-market position for some, but ever more women enter the labour market-either because they have to or because they want to. Modern societies are working societies. From a different point

\footnotetext{
17 Peter Schaber, 'Absolute Poverty' in Paulus Kaufmann et al. (eds) Humiliation, Degradation, Dehumanization: Human Dignity Violated, 1st edn (Dordrecht: Springer, 2011), pp. 155-156.
} 
of view, Christophe Dejours and Jean-Philippe Deranty have rightly written about the 'centrality of work' for many different relations in the social world. ${ }^{18}$

Work and labour are the sources for income, self-esteem, status and recognition. The life course, with its three main phases, is institutionalised around work and labour. ${ }^{19}$ One learns to get a job, then one has a job and then one retires. One works for oneself and one's family. One works to pay the bills and to feel a valued member of society. Alienation is bound to work, as is emancipation.

Work and labour also feed the public purse and the social security systems. The taxes on labour are an important income in all welfare states, and they are much more important than taxes on wealth. Also, in many countries social insurance-the safety net against illness, accidents and unemployment-is closely connected to work, as is the pension system. ${ }^{20}$ There are major differences between the welfare statesEsping-Andersen distinguished three kinds ${ }^{21}$-but the importance of work and labour is a common feature. The taxes and charges on labour differ; some states prefer a private system of social insurance and others have strict employment protection. However, not working is not a durable and viable option in any welfare state-except for a few who live from the work of others. Social policy is oriented towards the labour market. Reintegration and workfare point towards what really counts: paid work and employment. In a working society, work and labour are not just activities among others but they are value-loaded. Freedom, autonomy, responsibility, merit, self-realisation-the good life-are connected to them. Yet not all kinds of work count, just work that succeeds on the market, that is paid for. Unpaid work is a hobby, but only if one also has paid work; if one does not, then one's unpaid work is a waste of time and one should hurry to get a 'real' job. It might not be recognised as work at all. What value can an activity have if no one is willing to pay for it? Not much.

I think that we can understand poverty only if we think of it in this context of a working society that worships work and labour, that views an activity as valuable only if it is needed on the market, and that thinks that the market price is the best, maybe even the only indicator of the value of work. In a general sense every human society was and is a working society because the reproduction of human life relies on work, but in the particular sense that dominates modern societies, work has been narrowed to market success. The capitalistic market-which

\footnotetext{
18 Christophe Dejours and Jean-Philippe Deranty, 'The Centrality of Work', Critical Horizons, 11:2 (17 December 2010), pp. 167-180, doi: 10.1558/crit.v11i2.167

${ }^{19}$ Martin Kohli, 'The Institutionalization of the Life Course: Looking Back to Look Ahead,' Research in Human Development, 4:3-4 (14 November 2007), pp. 253-271, doi: 10.1080/15427600701663122

${ }^{20}$ Silja Häusermann, The Politics of Welfare State Reform in Continental Europe: Modernization in Hard Times, 1st edn, Cambridge Studies in Comparative Politics (Cambridge: Cambridge University Press, 2010); Janine Leschke, Unemployment Insurance and Non-standard Employment: Four European Countries in Comparison, 1st edn (Wiesbaden: VS Verlag für Sozialwissenschaften, 2008).

${ }^{21}$ Gøsta Esping-Andersen, The Three Worlds of Welfare Capitalism, 1st edn (Cambridge: Polity Press, 1990).
} 


\section{G. Schweiger}

is certainly not a free market-rules. Even some critical thinkers such as Axel Honneth bow before the market-as long as it is tamed.

From the sociopolitical perspective, the aim of contemporary Critical Theory is not the critique of capitalism as such, but rather of neoliberal capitalism. As I have pointed out, Honneth is fundamentally of the opinion that neoliberal, but not social-democratic, orders are problematic from the standpoint of recognition theory. Because regulated markets are components of the latter, it would be surprising if Honneth believed that markets in general were unsuited to determining the social usefulness of work. ${ }^{22}$

Yet it is still this market that produces poverty as it produces unemployment, winners and losers, precarious work, stress at work and burnt-out managers. Despite the fact that many things are changing, it was not very different in the good old times of the social democratic reign. ${ }^{23}$ One can be poor if one has a job and one can be poor if one does not have a job. ${ }^{24}$ That is not the important distinction, although unemployment and poverty often go hand in hand. However, regardless of whether one has a job or not, if one is poor, it means that one fails on the market. If one is poor in the sense that one has less income than the mentioned 60 per cent of the median, then one is poor because one's labour is not worth more. One is either paid nothing and depends on transfers from the social system or one has a job that is of such low quality, importance or value that one is paid much less than others. If one is poor in the sense of material deprivation, then it means that one is unable to generate enough income on the market to afford the items on the list, those items that the vast majority of one's fellow citizens view as normal, as basic. Being poor is a failure, a failure to take care of oneself even against the low standards of normality. One does not have to be a huge success on the market not to be poor, one does not have to be very smart or special, one has to be normal. That means having a job and getting a decent wage. Otherwise one has to blame oneself, because one is lacking the talents, the education or training, the flexibility, the diligence or the effort and willingness to take care of oneself. The slogan of the capitalistic market society is that everybody can get a job. One gets an education for free, one gets training and help from the employment agency, and the state is even willing to pay companies to give the unemployed jobs.

Yet still there is poverty, despite all the efforts of the poor and the state alike and all the money invested. There is either something wrong with the market or with the poor. That is what makes poverty humiliating. Even though the measures of poverty do not want to transport the blame and shame, they do. The deregulation and flexibilisation of the labour markets and the shift from welfare to workfare support

\footnotetext{
22 Hans-Christoph Schmidt am Busch, 'Can the Goals of the Frankfurt School Be Achieved by a Theory of Recognition?' in Hans-Christoph Schmidt am Busch and Christopher F. Zurn (eds) The Philosophy of Recognition: Historical and Contemporary Perspectives, 1st edn (Lanham, MD: Lexington Books, 2010), p. 268.

${ }^{23}$ Bruno Palier (ed.) A Long Goodbye to Bismarck? The Politics of Welfare Reform in Continental Europe (Amsterdam: Amsterdam University Press, 2010).

${ }^{24}$ Neil Fraser, Rodolfo Gutiérrez and Ramón Pena-Casas (eds), Working Poverty in Europe: a Comparative Approach, Work and Welfare in Europe (New York: Palgrave Macmillan, 2011); Gary S. Fields, Working Hard, Working Poor. A Global Journey, 1st edn (Oxford: Oxford University Press, 2012).
} 
the view that something is wrong with the poor, ${ }^{25}$ that the problem is not too much market but too little, that the pressure to work is not high enough, that living from social transfers is too good. All of this ignores what has long been known: that the unemployed do not need a stick to want to work, any work is enough of a carrot for them, that the working society is as strong in the minds and bodies of the poor as it is in the rich, that even those whose chances on the markets are limited-the old, the sick and single mothers and fathers-are mostly supporters of the market, that they want to work and take care of themselves and their families. The negative consequences of unemployment are hard enough, and not only on the income side. $^{26}$ The burden of unemployment and the marginalised position of the unemployed, which is much weaker than that of the employed, also hinder their organisation and protest. $^{27}$

The normality that is the benchmark for poverty may be income, goods and services or capabilities, but in the end, in a working society, it is work and labour. The welfare state can cushion the market-decommodification-but it does not, nor does it want to, replace the market or the centrality of work and labour. Poverty in the welfare state is always fought poverty, reduced poverty, but there is still poverty. ${ }^{28}$ The state invests enormous money in the social system and labour market policies but some just cannot get on their own feet. That is the message that comes with the label of being poor, which veils the economic and structural reasons of poverty.

\section{The Subject of Critique}

Poverty means to be humiliated and to be marked as a failure. This is not a subjective ruling, nor is it arbitrary, even if not all poor people feel humiliated and not all nonpoor people would support this evaluation. The exception proves the rule. Poverty is an integral part of any capitalistic society, and the poor or the unemployed are not standing on the outside looking in. The term 'social exclusion' might suggest that the poor are no longer inside or that there is a sphere where the social rules of capitalism do not apply, but that is a misleading understanding. Social exclusion means living at the bottom of society, but the rules still apply and they come down even harder on

25 Daniel Attas and Avner De-Shalit, 'Workfare: The Subjection of Labour', Journal of Applied Philosophy, 21 (December 2004), pp. 309-320, doi: 10.1111/j.0264-3758.2004.00284.x; Andranik Tangian, 'European Flexicurity: Concepts, Methodology and Policies', Transfer: European Review of Labour and Research, 13:4 (January 1, 2007), pp. 551-573, doi: 10.1177/102425890701300404

${ }^{26}$ Frances McKee-Ryan et al., 'Psychological and Physical Well-being During Unemployment: A MetaAnalytic Study', Journal of Applied Psychology, 90:1 (2005), pp. 53-76, doi: 10.1037/0021-9010.90.1.53; Connie R. Wanberg, 'The Individual Experience of Unemployment', Annual Review of Psychology, 63 (10 January 2012), pp. 369-396, doi: 10.1146/annurev-psych-120710-100500

27 Marco Giugni (ed.), The Contentious Politics of Unemployment in Europe: Welfare States and Political Opportunities, 1st edn (New York: Palgrave Macmillan, 2010).

28 Koen Caminada and Kees Goudswaard, 'Effectiveness of Poverty Reduction in the EU: A Descriptive Analysis', Poverty \& Public Policy, 1:2 (17 July 2009), doi: 10.2202/1944-2858.1023; Koen Caminada and Megan C. Martin, 'Differences in Anti-Poverty Approaches in Europe and The United States: A Cross-Atlantic Descriptive Policy Analysis', Poverty \& Public Policy, 3:2 (28 June 2011), doi: 10.2202/1944-2858.1153 
the excluded. ${ }^{29}$ Poverty means to be vulnerable and, as poverty research shows, it often means getting hurt numerous times. The multidimensionality of poverty translates into the multidimensionality of suffering: poverty, exclusion, low education, unemployment, illness, psychological pressure, addiction, violence, stigmatisation, harassment, humiliation, etc. Poverty is the proof that not everyone can be a winner and that losing really hurts.

Social critique has to take those processes of exclusion and the hardship of poverty seriously: they can serve as the basis for a better understanding of society and what critique should be all about. This is also the place where the subject cannot be replaced. Or can it? Social critique is ambiguous towards subjective experiences, as is poverty research. The position of the poor themselves is controversial. Do we trust them? Are they the 'real' experts? Or do we marginalise the poor again if we do not take them seriously?

The social philosophy of Honneth is a good example for this question. ${ }^{30}$ The poverty research of Sen is another one, although different. Honneth wants to take the subject seriously and give it a prominent place in his theory, as has been done by his predecessors of Critical Theory and Marxism. They saw in the oppressed working class the subject of history, and for Honneth it is still-with much less pathos-an important player in the struggle for recognition. ${ }^{31}$ However, it has been accompanied by other movements: those of women, black people, indigenous peoples and nowadays social protesters from all around the globe. The poor do not have a prominent place in Honneth's theory, maybe because their organisation is too weak, or their lifestyles, living conditions, problems or self-understanding are too scattered. Nonetheless I think that Honneth's theory can serve as a good example. It wants to take the subject, their experience of harm and suffering, not only seriously but as the starting point for social critique. One could say that the poor and their hardship motivate the critical inquiry of the intellectual in the first place.

To undertake an effective critique of society one must start by taking into account instances of injustice or violations of standards of justice. In contrast to its positive counterpart, the experience of injustice possesses greater normative bite. As such, for Honneth, no experience of injustice must be ignored even if its public expression is fraught with danger and difficulty. This approach to social justice and normativity is typical of the Frankfurt School, which grounds the motivation for social resistance and liberation movements not on grand theories of intellectuals but on people's everyday experience. ${ }^{32}$

29 Jane Millar, 'Social Exclusion and Social Policy Research: Defining Exclusion' in Dominic Abrams, Julie Christian and David Gordon (eds) Multidisciplinary Handbook of Social Exclusion Research, 1st edn (Chichester: John Wiley \& Sons, 2007), pp. 1-16.

${ }^{30}$ Gottfried Schweiger, 'Recognition and Social Exclusion. A recognition-theoretical Exploration of Poverty in Europe', Ethical Perspectives, 20:4 (December 2013), pp. 229-554.

31 Axel Honneth, The Struggle for Recognition: the Moral Grammar of Social Conflicts, 1st edn (Cambridge, MA: MIT Press, 1996).

${ }^{32}$ Renante Pilapil, 'Psychologization of Injustice? On Axel Honneth's Theory of Recognitive Justice', Ethical Perspectives, 18:1 (2011), p. 81. 
Honneth's critique understands itself as immanent or internal. ${ }^{33}$ It criticises the capitalistic - the neoliberal, to be precise-society because it fails its own standards and because this failure leads to the experience of various forms of injustice and suffering. The promise of modern society is that everybody should be able to live a good life-to realise themselves-but that is not what is happening. Honneth is right when he claims that we need the diverse and authentic expressions of harm to fully understand injustice. The victims themselves have to point the theorist towards what is wrong, because there are so many subtle forms of humiliation and deprivation. Yet that is not enough. Suffering might be enough for to motivate a political or social movement but it is not enough for social critique. A theory needs more. Christopher Zurn and Nancy Fraser have criticised the psychologisation of critique by Honneth and stated that objective standards or criteria are needed to answer the challenge of alienation and to dismiss the false claims of the righteously oppressed Neonazis, racists and sexists. They make clear that any critique of social injustices, of poverty and capitalism, needs more substance and cannot rest on the experience of suffering and harm alone.

Thus, for example, a critical theory should be able to dismiss, on principled grounds, claims for expanded recognition put forth by racist hate groups. It should also be able to demonstrate that cultural stereotypes of feminine sexuality may subordinate women through legal definitions of rape-even when these definitions are not generally detected as harmful by women. In other words, a critical theory of recognition must be able to deal with what we might call the problems of the malevolent claimant and of false consciousness. ${ }^{34}$

The same is true for the poor. Being poor does not mean being a good person. The experience of poverty and unemployment can bring forward envy, hate and violence. The poor can lie, and they sometimes do lie about their welfare and condition. Many of the poor are not progressive and many of them are prone to populist, right-wing arguments. Yet the problem goes deeper. If we want to give the poor a prominent place in our own theories, do they have a say in what poverty is all along? How do we weight their opinion and their judgements? Surprisingly, many poor people are also happy and feel good despite their situation. They comfort themselves. Do we-the theorists-have to tell them that their life is a misery and that they should be protesting rather than watching TV? Most poverty research is distant to the poorwhich does not mean that they are not closely surveyed-and participatory approaches are still the exception. ${ }^{35}$ Is this also how social critique should work?

33 Axel Honneth, 'Redistribution as Recognition: A Response to Nancy Fraser,' in Nancy Fraser and Axel Honneth, Redistribution or Recognition?: a Political-Philosophical Exchange, 1st edn (London: Verso, 2003), 110-197; Antti Kauppinen, 'Reason, Recognition, and Internal Critique', Inquiry, 45:4 (2002), pp. 479-498; Schmidt am Busch, 'Can the Goals of the Frankfurt School Be Achieved by a Theory of Recognition?', op. cit.

${ }^{34}$ Christopher F. Zurn, 'Identity or Status? Struggles over "Recognition" in Fraser, Honneth, and Taylor', Constellations, 10:4 (December 2003), p. 535, doi: 10.1046/j.1351-0487.2003.00351.x

35 Robert Chambers, Poverty Research: Methodologies, Mindsets and Multidimensionality, Working Paper (Brighton: Institute of Development Studies, December 2007), http://www.ids.ac.uk/download.cfm?file=wp293. pdf; Andy Norton, A Rough Guide to PPAs: Participatory Poverty Assessment: an Introduction to Theory and Practice (London: Centre for Aid and Public Expenditure, Overseas Development Institute, 2001), http://info. worldbank.org/etools/docs/library/238411/ppa.pdf 
Distant, relying on experts, judging what is good and what is wrong, what is an experience of harm that should be taken seriously, and what is an experience that is just not so bad. Sen is a prominent advocate of such reluctance and scepticism. The poor are not good informants of their own situation, not for the definition of poverty and not for the existence of injustice and inequality.

The most blatant forms of inequalities and exploitations survive in the world through making allies out of the deprived and the exploited. The underdog learns to bear the burden so well that he or she overlooks the burden itself. Discontent is replaced by acceptance, hopeless rebellion by conformist quiet, and ... suffering and anger by cheerful endurance. As people learn to survive to adjust to the existing horrors by sheer necessity of uneventful survival, the horrors look less terrible in the metric of utilities. ${ }^{36}$

Sen calls this 'adaptive preferences', ${ }^{37}$ and this term can indeed be a good framework to explain why people so often keep silent, why the protests are limited and the market-based working society in the welfare states of the north and west is still underway-again the exception of the protests in Greece, London and Portugal proves the rule. Sen makes a convincing argument and Zurn and Fraser do the same.

There is a need for objectivity, despite the fact that it is not clear where to find and how to judge this objectivity. ${ }^{38}$ Scientific research is still the best way there is to gather knowledge, although today it is clearer than ever that it is flawed. Social critique is impossible without such knowledge, but this does not dismiss the insight that there are good reasons to take the poor seriously. In the end, what is social critique about if it is not about helping to make the living of the oppressed and poor better? Criticising injustice always implies that it should vanish. Therefore, every attempt at social critique has to find a balance between distance and closeness, between the opinions of experts and the persons concerned, between objective criteria and subjective experience. There is a dialectical relation. Poverty knowledge, the life of the poor, social critique and subjective experience are intertwined and they cannot replace each other. They have to complement each other because-to use Honneth's notion-there is a 'surplus in validity ${ }^{39}$ in poverty knowledge and the experiences of the poor.

\section{Conclusion}

Social critique needs the poor. Their ongoing existence and their deeply rooted humiliation tell us a lot about society, about the welfare state, about the labour

\footnotetext{
36 Amartya Sen, 'Rights and Capabilities' in Resources, Values, and Development: Expanded Edition, 1st edn (Cambridge, MA: Harvard University Press, 1997), pp. 308-309.

37 Miriam Teschl and Flavio Comim, 'Adaptive Preferences and Capabilities: Some Preliminary Conceptual Explorations', Review of Social Economy, 63:2 (June 2005), pp. 229-247, doi: 10.1080/00346760500130374

38 Gunter Graf and Gottfried Schweiger, 'Capabilities, Recognition and the Philosophical Evaluation of Poverty: A Discussion of Issues of Justification and the Role of Subjective Experiences', International Critical Thought, 3:3 (August 2013), pp. 282-296, doi: 10.1080/21598282.2013.818088

39 Honneth, 'Redistribution as Recognition: A Response to Nancy Fraser', op. cit., p. 186.
} 
market and about capitalism. Critical theories, whether in philosophy, the social sciences or poverty research, have to give the poor a place and a voice. Where we put the poor also says a lot about our theories. It is therefore illuminating that poverty is not even mentioned in most of the literature on the recognition approach, which claims to be a new paradigm for social critique. ${ }^{40}$ It is also illuminating that poverty research is dominated by counting and surveying the poor instead of uncovering the harm done and asking for the structural causes. Since the crisis poverty is back on the political and scientific agenda also in the USA and Europe. Yet do we take the poor seriously? We should examine the poverty knowledge, the thick descriptions and the large-scale data as we should be critical of our own theories that too often subjugate the poor as mere objects. We need the whole range of poverty research, we have to take a good look at what standards of normality and judgements come with it-often not declared-also because many of the poor are silent. Those in more powerful and secure positions in academia and elsewhere should not wait until they come to us and start to speak out; instead we have to listen more carefully.

\footnotetext{
40 Shane O'Neill and Nicholas H. Smith (eds), Recognition Theory as Social Research: Investigating the Dynamics of Social Conflict, 1st edn (Basingstoke: Palgrave Macmillan, 2012).
} 